\title{
Did Fátima de Madrid Really Exist?
}

\author{
Núñez Valdés, Juan ${ }^{\mathrm{a}^{*}}$ \\ a Departamento de Geometría y Topología, Facultad de Matemáticas, Universidad de Sevilla, Sevilla (Spain). \\ Teléfono: 34 954557962, Fax: 34954557970 \\ *Corresponding author's email address: jnvaldes@us.es.
}

\begin{abstract}
A R T I C L E I N F O
Received: 03-01-2016

Accepted: 31-01-2016

Available online: 20-02-2016

Keywords:

\section{A B S T R A C T}

In this paper we firstly pose the question of whether Fátima de Madrid, a Spanish mathematician woman allegedly born in Madrid, X-XI centuries, really existed or, on the contrary, she is only a product of the imagination of several authors wellintentioned and secondly, under the premise that she really existed, we show her life and work according to the consulted sources and our own research.
\end{abstract}

Fátima de Madrid,

Maslama al-Mayriti,

Old Spanish mathematician women,

JEL Classification:

C00; I29; Z00.

(C) 2016 The Authors. This is an open access article under the terms of the Creative Commons Attribution License 4.0, which allows use, distribution and reproduction in any medium, provided the original work is properly cited.

DOI: http://dx.doi.org/10.18533/rss.v1i2.20

\subsection{Introduction}

In Spain, when someone is asked if relevant Spanish female mathematicians have existed, the answer is usually negative, and this response is given not just by the average citizen, but also by undergraduates or graduates. Moreover, if the condition that these women were born before the twentieth century is also added to the question, then the "no" is even more emphatic. However, this answer might not be accurate. In this paper we dscribe the life and work of one of them, Fátima de Madrid, born before the aforementioned century, and very well considered his contemporaries according to literature, although, and in all honesty, the few sources found in the literature make it impossible to ensure her existence.

In general, the history of scientific women, especially if they lived in other centuries, does not need inventive fantasy to reassert itself; in spite of that, very few references in the literature about them are normally preserved and usually they are not authenticated in an adequate way.

This is the case, for instance, of a Spanish woman, Fátima from Madrid, from who we do not know really if she lived or simply she is a figure invented by some historian (in which case we would like to believe that this was not done intentionally), whose contributions have spread in time without being finally rectified. The case is that we can ask ourselves: Fátima de Madrid, myth or reality?

To be honest, we have to say that most specialists of Arabic, Spanish and non-Spanish, do not believe in the existence of this woman, but there are others who think otherwise. Indeed, taken from the calendar produced by the "Ella es una Astrónoma" group in Spain, can be read verbatim (web1): 
Fătima de Madrid (? 10 $10^{\text {th }}-11^{\text {th }}$ century) was the daughter of the astronomer and scientist Maslama alMayriti (whose name means Man from Madrid). She wrote several works which are known as 'Corrections from Fatima' and she worked with her father on astronomical and mathematical investigations. They edited and corrected 'The Astronomical Tables of al-Khwarizmi', adjusting them to the meridian passing through Cordoba. They also worked on zijes; these are Arabic tables which include calendars, positions of the Sun, Moon and planets, trigonometric and spherical astronomy functions, eclipses and Moon visibility, and other information.

Therefore this paper is the main indication that shows what is believed to be known in a reliable manner about this woman, about her life and her work, since to categorically affirm or deny her existence is nowadays unfeasible.

The structure of this paper is as follows: after this Introduction, Section 2 indicates the research framework followed in the writing of the manuscript. Section 3 includes our main findings and is devoted to show the life and scientific work of Fátima of Madrid. Finally, a last conclusion section is included.

\subsection{Theoretical Framework}

Although the level of current research on any topic is very high nowadays, it is also true that, as it has been just commented, specific gaps often appear in our knowledge of some facts, especially if they refer to events that occurred in the Old and Middle Ages of our civilization. Indeed, the scarcity of trustworthy sources makes very difficult, most of the time, ensure the authenticity of these events

In this context, our contribution tries to clarify a very sharp controversy among different investigators, the truly existence of the Spanish astronomer Fátima de Madrid.

\section{$2.1 \quad$ Literature review}

In the literature there are two types of sources related to the figure of Fátima de Madrid: those which affirm her existence and others who deny it. Between the former can be considered web2, 4; 8; 9; 10;11; 14; and 15, for example, whereas in web 3; 5; 6 and 7, that existence is rejected.

Therefore it is not surprising that the scientific community is divided between those who believe in the existence of this woman and those who think that she really did not exist and that his name appears because misinformation that has passed down from generation to generation.

\section{$2.2 \quad$ Procedure and methodology}

Besides performing many personal interviews with both astronomers and historians as leading scholars of Arabian culture, the author has consulted many resources of any type in his research, encyclopaedic, bibliographic and of computer type, in order to find the answer to the following question: Did Fátima de Madrid really exist?

After this research, the answer of the author is affirmative. Therefore, in the next section, the life and scientific work of the Spanish astronomer Fátima de Madrid, is described, as well as the geographical and historical context in which she lived. The main findings of the paper are exposed in that section.

\subsection{Policy implications}

Since that this paper tries to resolve a historical controversy, and thus it is of an essentially biographical type, it is not easy to draw political implications, although some could be considered, like those related with the Arabian world or gender subjects.

\subsection{Fátima de Madrid}

Before we start the biography of this woman, we consider it appropriate first to contextualize both the time and the places where her life took place, as well as to give a brief biography of the character who is supposed to be her father, in order that certain episodes of her life can be better understood. All this provided that the actual existence of this woman is admitted, as will be discussed later. 
In the time that Fátima presumably lived, tenth century, Cordoba, was called the "Pearl of the West", and lived moments of great splendour. During that period the Great Mosque was completed, became an important centre of pilgrimage for Muslims and has been described as "the world's most beautiful Muslim shrine." In a publication of that time it can be read that "its sacred nature is only surpassed by Mecca and to visit it absolves the faithful from the obligation to make the pilgrimage to Arabia"(see (web11) for details).

At that time, the period of greater glory in the Caliphate, Cordoba became the largest city in Europe and the world (with the possible exception of Constantinople) and perhaps the most cultured. It had 450,000 inhabitants in the year 1000 (for some historians this figure goes back more than a million), a university, thousand six hundred mosques, three hundred thousand houses and eighty thousand shops. All this confirms that it was a financial, cultural, artistic centre of the first order after the enthronement of the Caliph Al-Hakam II, who is credited with the creation of a library that housed 400,000 volumes (the largest in the world).

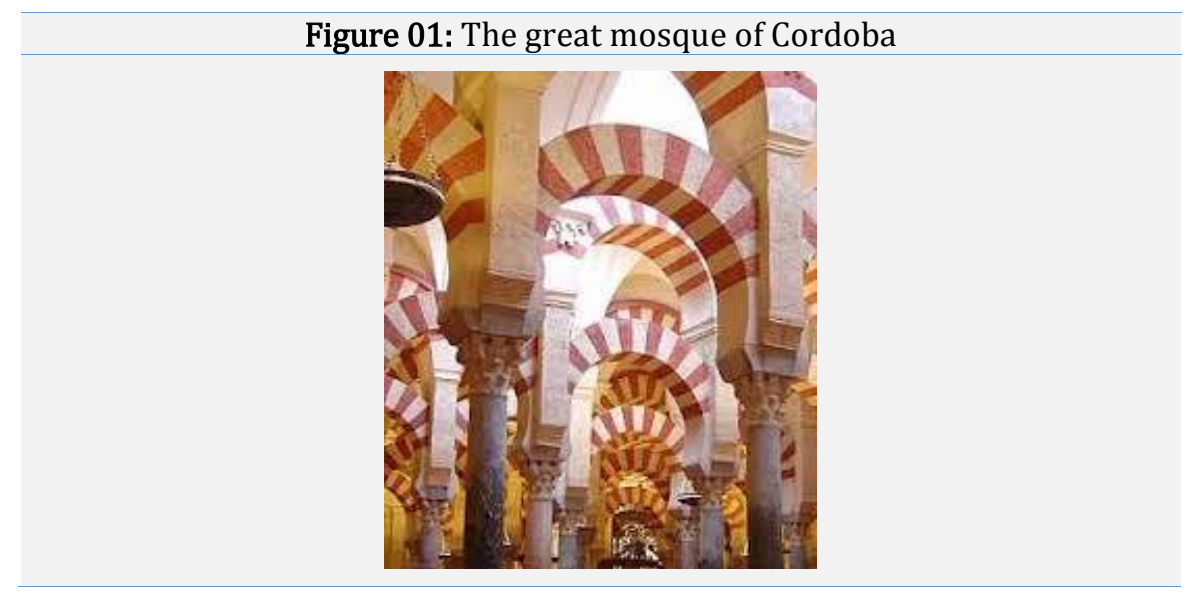

However, another city in Al-Andalus also began to highlight at this time. Indeed, as it is well known, in Madrid, a city founded by Muslims, whose name is of Arabic origin, were soon born famous researchers who developed many sciences, including astronomy and alchemy. The translations into Latin of the writings that reflected this research had a major influence in the European Renaissance. Note that apart from the Qur'anic and theological studies, Islamic knowledge was organized into two main groups: the Astronomical-Mathematician, whose main exponent was Maslama (from who we will now speak) and Physical-Medical-Botanical, around Abulcasis from Cordoba. There is no doubt that Andalusian culture specially highlighted in the scientific field. The contrast with the situation that at that time offered science in the Christian world is overwhelming. As an example, Al-Andalus was the channel through which the Indian numbering system which finished, replacing Roman numerals' spread to the rest of European Christianity. Certainly, Al-Andalus was in close contact with the rest of the Muslim world, especially from the ninth century, and this allowed it to participate in the comprehensive collection of literary, philosophical and scientific texts that Islamic scholars collected from both the Greek world as Persian and Indian. After being duly translated, this was a cornerstone for the studies of Renaissance scientists.

One of these researchers was the Hispanic-Arabian astronomer, philosopher, polygraph and mathematician Abu-l-Qasim Maslama ibn Ahmad Al-Faradi al-Hasib al-Qurtubi al-Mayriti. He was born, as indicated by their nisba (patronymic of the Arabian name) in Mayrit, Madrid today, mid-tenth century, and died in Cordoba between 1007 and 1008. Maslama is apparently the first citizen from Madrid whose name is known, although the names of previous people who previously lived in the city, as the former governors appointed by the Caliphate of Cordoba, seem also known.

It appears that Maslama was established early in Cordoba, which was, as already mentioned, the capital of the Caliphate of Al-Andalus. He was a disciple of the geometer Abd al-Gafir Ibn Muhammad. Maslana became one of the most reputable intellectuals of the Caliphate; indeed, he won the surname "Euclid of Spain". 
Figure 02: Maslama ibn Ahmad Al-Mayrit

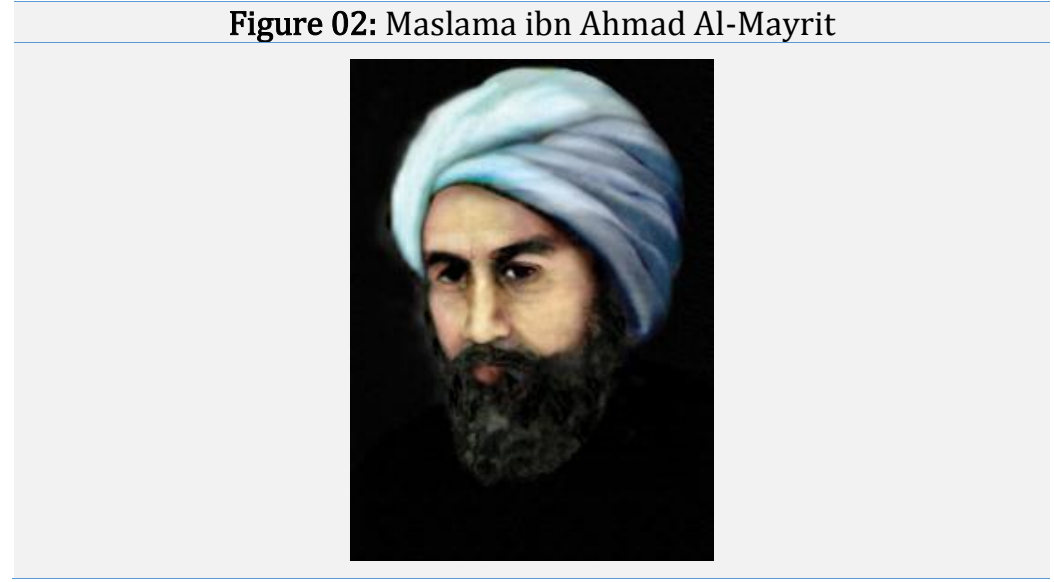

In fact, Maslama was a great astronomer. In the year 979, he performed astronomical observations and summarized and adopted the tables by Al- Khwarizmi to the Cordoba meridian. This version of Maslama would be translated into Latin by the English sage Adelard of Bath.

Besides introducing in Al-Andalus (and by extension in Christian Europe) this key work by the "Father of Algebra", Maslama did the same with the encyclopaedic knowledge of the "Brethren of Purity".

Maslama was a master of pure philosophy, exact science, astral precision and the melody of numbers. He also perfected the astrolabe, translated the "Planisphere" by Ptolemy into Arabic and scored it. This knowledge would then be transferred to the Christian kingdoms, serving to build the first astrolabes, like the one of Barcelona (or Destombes). His láqab (nickname) Al-Faradi makes their abilities apparent.

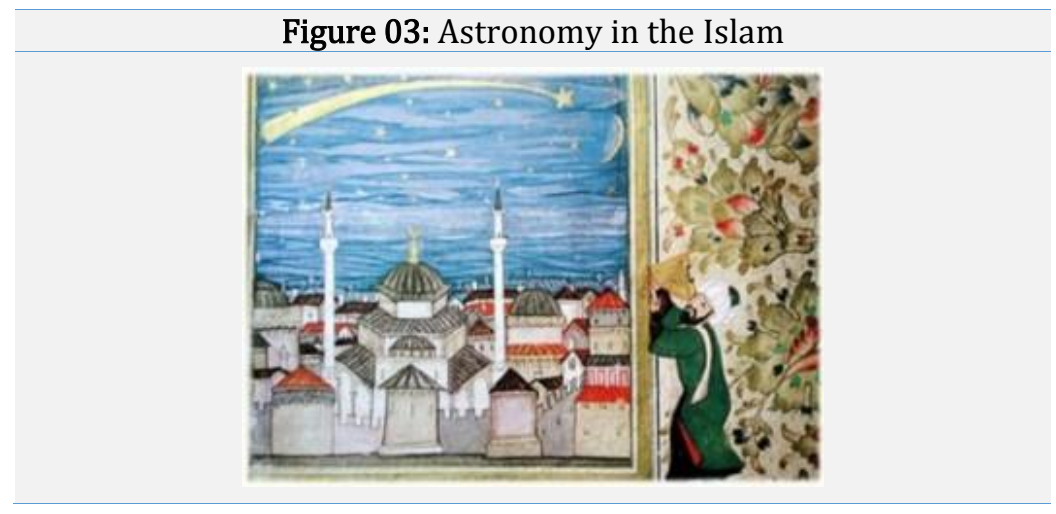

He was also astrologist of Almanzor, usually indicating him when to begin their campaigns, and it is said that he forecasted the end of the caliphate and the details of how it would happen long before its occurrence.

His many works include the "Treaty of Astrolabe", which is preserved in the library of the Monastery of El Escorial with the number 967 of the Arab Fund; the "Extract of the Tables by Al-Battani, for the position of the stars and planets equations"; the "Book of Arithmetic practice"; the "Theory of the perfection of the sciences numerals" (in Arabian: Fi taman ilm al-Hadad), and also the "Commercial Calculus" (al-Mu'amalat).

He has also credited a true encyclopaedia that surely must be an adaptation or a new form of the already cited of the "Brethren of Purity" and which consists of a set of fifty-two studies of very different subjects (web12).

Later, his work would be expanded and improved by another person of the Al-Andalus, the astronomer and mathematician Abu Ibrahim Ibn Yahya al-Naqqás (the engraver), called al-Zarqali by his contemporaries, which was known in the Latin world and posterity as Azarquiel. He was born in Cordoba over 1029 and died in Toledo in 1087.

According to Juan Vernet Ginés (a Spanish specialist of Arabic and historian), it can be said that Maslama "is the most important personage of the scientific world in the Cordoba Caliphate and the father of the subsequent expansion and flourishing of mathematics in Al-Andalus." 
After this preamble, now we may undertake the study of the figure of Fátima de Madrid, and it seems appropriate in the first place to clarify why there are reasonable doubts about the true existence of her person.

Indeed, in some bibliographical sources and websites (web11, 13 and 14, for instance) it can be read that Fátima de Madrid was a remarkable Muslim astronomer of the tenth century, although there is no record of the exact date of her birth. However, others sources questioned her existence. Ángel Requena Fraile, a Spanish historian specialized in Mathematics (see web10) states that:

"Culture in Spanish language has a huge debt to the Espasa Encyclopaedia. This vast and ambitious work, more often updated, has been the source of consultation and reference for any researcher ... But in any project as ambitious as this one there are errata, someone unscrupulous or some careless copyist. So a few myths are created, which are not documented, nor clothed by other sources, that refer to personages who should not be in the stories rather than myths.

Francisco Vera, who is considered by many people as the father of the historiography of science in Spain, already warned when we he inquired about a geometer, Bishop of Calahorra in the Visigoth era, called Luciniano, that appears only in the Espasa and in no other sources.

We have this situation with Fátima, the clever daughter of Maslama. We find something similar to what happens with Luciniano. There is no reference, no original or reliable source on which to stand.

We reproduce the details of the sheet in the Espasa Encyclopaedia:

"FATIMA. Biog. Astronomer from Madrid, daughter of the celebrated astronomer Mosama-ben-Ahmed el-Mageritti (from Madrid) wrote notable works on astronomy that made her famous in the late tenth century (IV in the Hijrah) in the Moorish quarter of Madrid, where they were known as corrections of Fatima, and helped his father on the writing of several books, including the Treaty on the Astrolabe, preserved in the monastery of El Escorial "(Espasa-Calpe, Volume 23. Edition of 1924 of the Illustrated European American Universal Encyclopaedia. "

Abounding on this, Manuela Marín, specialist in history and biography of Al-Andalus, holds the view that Fátima did not exist when talking about Maslama al-Majriti. She affirms that (Marin, 2011, p. 191):

"It is, therefore, the most illustrious of the Andalusia from Madrid, and it did not need to be invented, as it has been the case, a historically nonexistent daughter of him, which has been called" Fátima de Madrid ", which has amazingly been included in the "Astronomers who made history" calendar, published to mark the International Year of Astronomy (2009). The mistake, which comes from an old edition of the Espasa Encyclopaedia, has been replicated uncritically and it is time to get rid, although its abundant circulating on the Internet does not give much hope in that regard".

Figure 04: "Astronomers who made history" Calendar

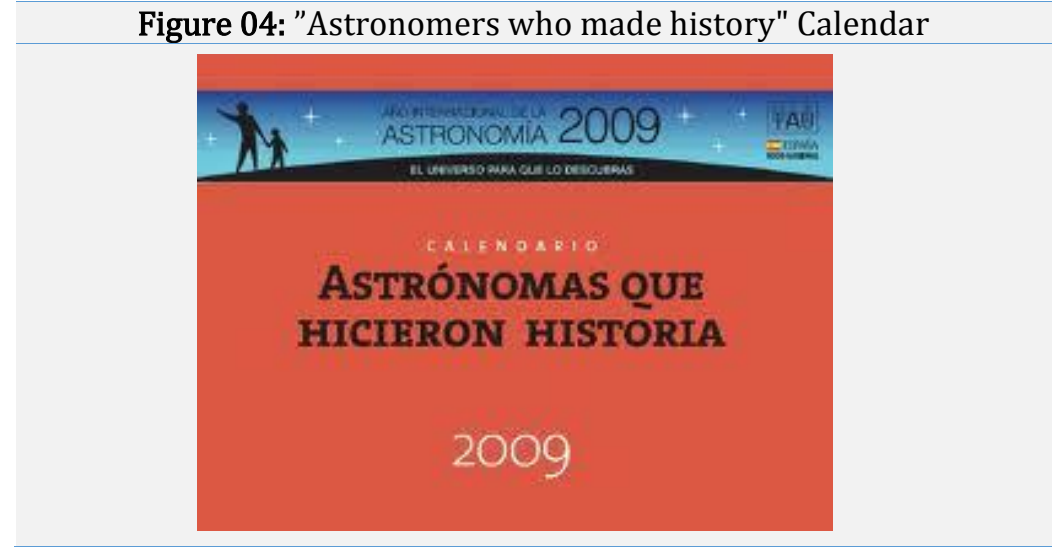

Nevertheless, if we believe in several other sources (see (Segura 1998) or (web13), for example), Fátima de Madrid, born in Madrid, X-XI centuries, was the daughter of the aforementioned famous polygraph and astronomer Maslama al-Majriti (whose name means "man from Madrid"). Fátima spent much of her life in Cordoba, when that city was the centre of knowledge. 


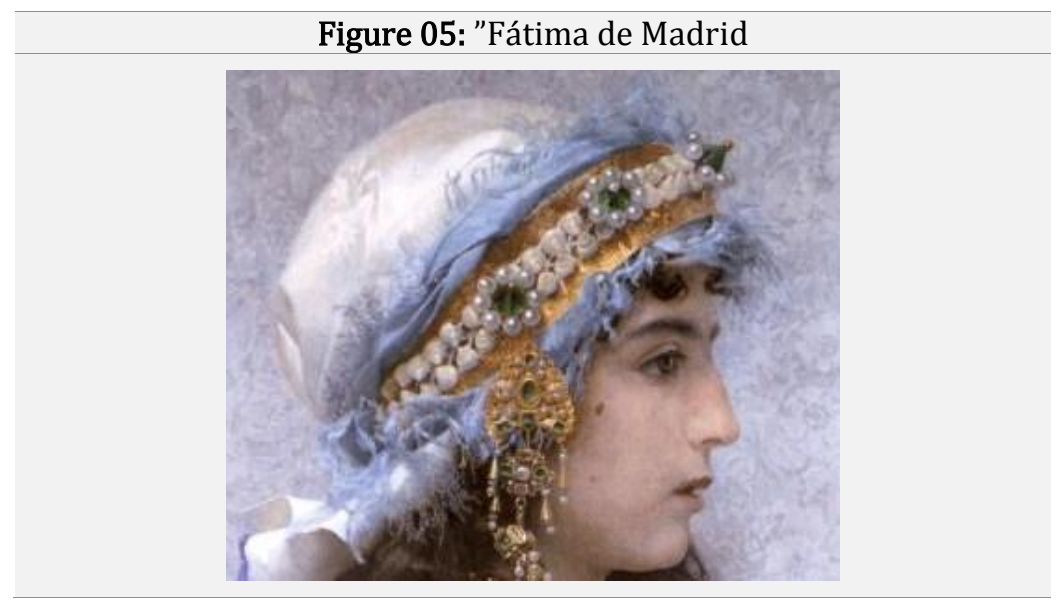

Fátima worked closely with her father on Astronomy and Mathematics, learning in particular to measure the height of the stars on the horizon. On these observations she wrote the famous "Corrections of Fátima", which featured an updated version of the existing knowledge at that time.

She also made corrections to the "Almagest" of Ptolemy, and found mistakes on the calculation of eclipses. Editions and corrections of Astronomical Tables were taken into consideration in that book, since the goal of Fátima and her father was the adaptation of the original tables to the time and place in which they were living. So, for example, they replaced the Persian solar calendar that was used in the tables of al-Khwarizmi by the Muslim lunar calendar and they specifically adapted some tables to the meridian and geographical coordinates of Cordoba, taking it as a reference for all calculations.

The father and his daughter also translated the numeration of the Persian years to Arabs years and determined the average positions of the planets for the first day of the Hijra. The Persians years had 365 days while Maslama and his daughter used the Muslim lunar year of 354 or 355 days. These new adapted tables, as indicated by scholars, are simpler to use and give more accurate results. They studied also calendars, calculations of the true positions of the Sun, Moon and planets, tables of sins and tangents, spherical astronomy, astrological charts, calculations parallax, eclipses and visibility of the Moon.

Her work entitled "A Treatise on the Astrolabe", about the use of this instrument is still preserved in the library of the Escorial Monastery; however, "Corrections of Fátima", which is a work that no investigator has been unable to find in any library.

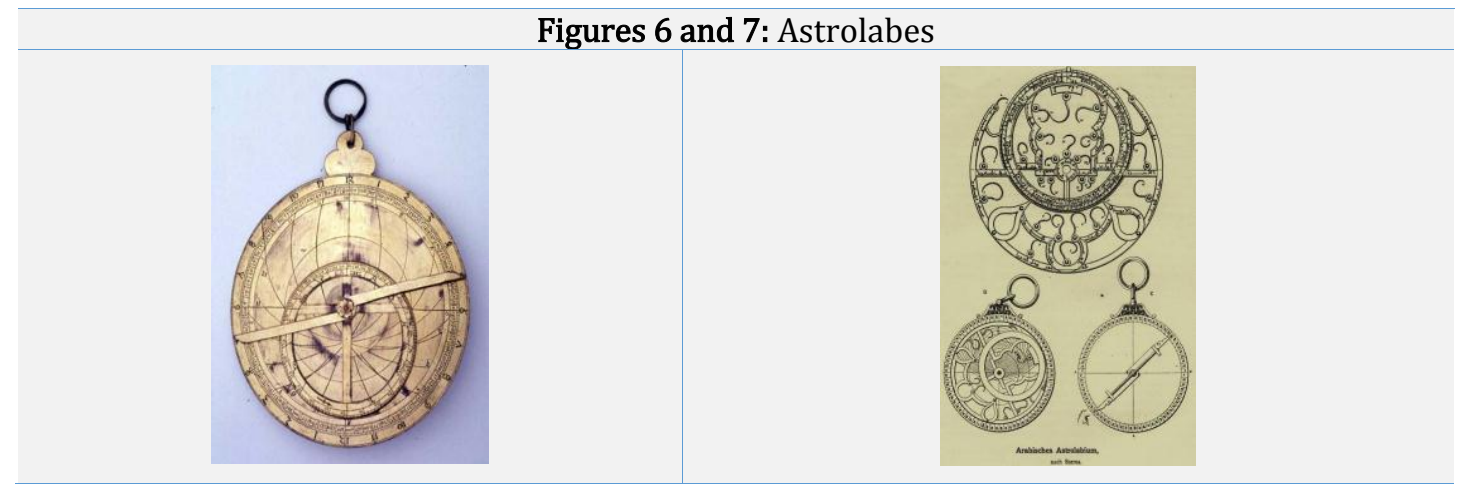

For all alleged reasons, Fátima was included in the "Astronomers who made history" Calendar, created in 2009 to mark the International Year of Astronomy, which contains among other things, astronomical events and dates of birth and death of the main female astronomers in history (web13).

\subsection{Conclusions}

It has been repeatedly indicated throughout the text that the main objective of this paper is to resolve the controversy surrounding the figure of Fátima de Madrid, presumably a Spanish astronomer born in X-XI 
centuries, whose existence is doubted by many researchers. To get this goal, many bibliographic, encyclopaedic and computer sources have been analyzed.

At this respect, the author believes that Fátima de Madrid really existed, although it is also true that it is not possible to reach a definite conclusion on this convoluted controversy. The figure of his father, Maslama, is however widely recognized.

This opinion of the author is based on the fact that the sources favourable to the existence of Fátima de Madrid (mainly web2, 4; 8; 9; 10; 11; 14 and 15, for example) are not personal websites or blogs, but correspond to official websites of entities or groups that belong in most cases to the world of the Astronomy, and therefore seem more reliable. However, among the non-favourable sources, there are of two types; those which do not directly cite Fátima as belonging to the group of female astronomers and those which explicitly deny her existence.

So, as a final conclusion and having in mind that it is not easy to deduce policy implications of the paper, because it tries to resolve a historical controversy, and it is of an essentially biographical type (although some more particular policy implications could be considered, like those related with the Arabian world or gender subjects), the fact is that the figure of Fátima de Madrid is totally unquestionable for many researchers, (at this respect, in (web14) can be read the text (in Spanish) of the Figure 8), whereas for others this woman is simply a mere fantasy.

As it has been showed in the previous paragraphs, for many researchers, the figure of Fátima de Madrid is really unquestionable (for example, in (web7) can be read the text (in Spanish) of the Figure 8), whereas for others this woman is simply a mere fantasy.

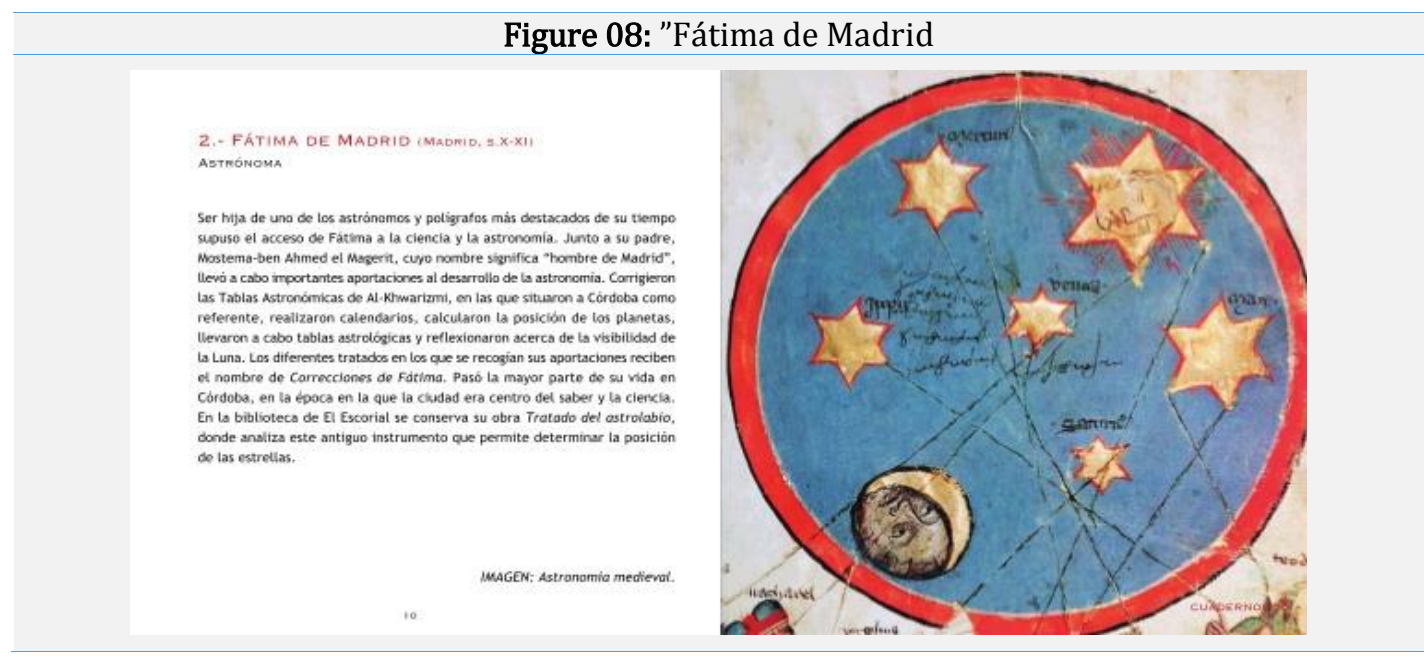

\section{References}

Marín, Manuela (2011). "Arabismo en Madrid", en Daniel Gil Flores (ed.), De Maŷrit a Madrid. Madrid y los árabes, del siglo IX al siglo XXI, Madrid/Barcelona: Casa Árabe/Lunwerg.

Segura Graíño, Cristina (1998). Diccionario de mujeres en la historia, Madrid: Espasa-Calpe, 1008, ISBN 84-2398631-4.

[web1] http://www.sheisanastronomer.org/index.php/history/fatima-de-madrid(on Fátima de Madrid).

[web2] http://www.astronomia-iniciacion.com/mujeres-astronomas/mujeres-astronomas.html (on Astronomer Women).

[web3]

http://www.astronomia2009.es/Proyectos pilares/Ella es una Astronoma/Astronomas que hicieron historia Podcasts.html (on Astronomer Women).

[web4] http://www.wisphysics.es/2009/12/ano-internacional-de-la-astronomia-mujeres-astronomas SI 4(on Astronomer Women).

[web5] http://www.rsme.es/comis/mujmat/documentos/mujeres_web.pdf (on Fátima de Madrid).

[web6] http://singenerodedudas.com/2003_2012/tirnamban/587/las-mujeres-en-la-historia-de-la-ciencia (on Women in Science). 
[web7]https://es.wikipedia.org/wiki/Categor\%C3\%ADa:Mujeres de la_Edad_Media en_Espa\%C3\%B1a ～(on Fátima de Madrid).

[web8] https://www.google.es/interstitial?url=http://astrojem.com/mujeres/fatimademadrid.html (on Fátima de Madrid).

[web9] https://verbiclara.wordpress.com/2009/01/30/fatima-de-madrid-siglos-x-xii/ (on Fátima de Madrid).

[web10] Requena Fraile, Ángel.

http://www.andalucia.cc/viva/mujer/vidas/fatima de madrid.html (on Fátima de Madrid).

[web11] http://dl.dropbox.com/u/22820842/Mujeres\%20astronom\%C3\%ADa/fatima\%20ok.pdf (on Fátima de Madrid).

[web12]http://www.webislam.com/articulos/39343-maslama_almayriti_el_primer_cientifico_madrileno.html (on Maslama Almayriti).

[web13] http://www.astronomia2009.es/Documentos/ELLA/Calendario_Astronomas_alta-resolucion.pdf (From "Calendario Astrónomas que hicieron historia" (2009) on Fátima de Madrid).

[web14] http://es.slideshare.net/LaGateradelaVilla/gatas-veinte-mujeres-de-madrid (on Women from Madrid).

[web15] http://mujericolas.blogspot.com.es/2013/01/fatima-de-madridverdad-o-leyendamujer.html ） (on

Fátima de Madrid). 